\title{
Developing Students' Reading Ability through Extensive Reading
}

\author{
Fanshao Meng \\ College English Department, Xuchang University \\ Xuchang 461000, China \\ E-mail: springmfshmfsh@yahoo.com.cn
}

\begin{abstract}
A good reading competence is a necessity for those studying English for academic and occupational purposes. Based on the results of previous research, theory and practice on L2 Extensive Reading, this paper analyses current situation for teaching and learning reading in our Chinese universities and proposes practical applications of extensive reading to a Chinese university, which is sure to improve students' reading competence as well as their linguistic capabilities. It attempts to provide some pedagogical implications to the foreign language teaching and learning.
\end{abstract}

Keywords: Extensive reading, Reading competence, Sustained silent reading, Out-of-class pleasure reading

\section{Introduction}

Reading is a source of learning and a source of enjoyment (Nation, 2005). In a second, particularly a foreign language situation, a good reading competence is a necessity for those studying English for academic and occupational purposes and many curricula therefore devote large amounts of time to reading lessons in order to achieve such competence. Yet despite years of instruction and practice in reading, many EFL students have difficulty in making sense of texts they want to read, seem to read considerably more slowly than they read in their first language, and feel less confident about reading in English. Of course, there are a number of possible reasons for this, but this is partly due to the way reading is approached in the language class.

\section{Current Situation for Teaching and Learning Reading in Chinese Universities}

The perceived role of English in international economic success has led Chinese government to require English courses at all levels of the education system. Based on the College English Curriculum Requirements issued by the Ministry of Education in January 2004, College English, an integral part of higher education, is a required course for undergraduate students for the first four semesters. Although the College English Curriculum Requirements lay great emphasis on the development of students' listening and speaking skills, English instruction at the university level is largely devoted to reading as it has been intricately intertwined with language teaching itself.

The textbooks used in the college English classes are mainly designed for intensive reading courses and are well above the students' current comprehension levels. They include short and authentic texts followed by a variety of exercises that encourage students to study vocabulary and grammar because they know they will be given tests and quizzes, or at least they will be asked questions in class that demand a detailed knowledge of vocabulary, structure, and comprehension details (Field, 2002).

Teachers control the conditions of reading by instructing, explaining and illustrating vocabulary, grammar and sentence formation, teaching reading strategies and testing students' comprehension in the hope to help students to learn English, which turns reading into a process of detailed study, memorization, analysis and guessing (Field, 2002). Urquhart and Weir (1998) describe this kind of reading lesson as 'testing, but not teaching'. In addition, as students are required to pass the CET-4 or CET-6 (national college English test) after completing the first four-semester foreign language requirement, reading is therefore geared to tests and seen chiefly as a means to learn vocabulary and grammar which would help students in the tests. The use of reading as a means to learn something extrinsic is common in almost all the EFL settings all over the world. Urquhart and Weir state (1998:195) 'many teachers see one of their key roles in the reading classroom as expanding vocabulary knowledge and developing learners' ability to continue to increase their vocabulary'. This is almost certainly an ill-understood cyclical process at work, whereby knowing something of the language helps students to acquire more language, which in turn helps students to read better, and so on. Such a view that reading feeds language learning fails to promote extensive reading skills and can even help to fossilize poor reading styles, thus hindering students from ever reading efficiency $(\mathrm{Li}, 1984)$. This also goes against the top ten principles for teaching foreign language reading discussed by Ray Williams (1986).

Obviously, the increasing enrollment of university students from 1999 in China pushed college English teaching to confront with a new challenge: the inexorable trend of large-class teaching in many universities. According to the statistics of the survey conducted by the National College English Committee in 2006, the average number of students 
in college English classes surpassed 60 in 2005. As far as my university is concerned, in the fall semester of 2006, there were 36 large classes with about 70 students, making up approximately $75 \%$ of college English classes. Owing to the widely acknowledged difficulty of managing a large class, most teachers naturally adopt a traditional teacher-centered approach for college English teaching.

As a result, through years of learning to read in English, students have managed to learn large amounts of vocabulary and every subtle grammatical rule by heart, but they cannot read well enough for information or for pleasure and relaxation, being able to decode only at the sentence level. Such a situation for teaching reading in Chinese universities leads to one obvious instructional issue: extensive reading is part of the ESL or EFL curricula in many settings, but has attracted comparatively little attention, which was examined as the sixth of Grabe's (1995a) dilemmas emphasizing the need for extensive reading in most L2 contexts.

Considering that extensive reading is still the missing ingredient in the EFL context of this Chinese university and there is a pressing need for additional reading instruction and practice, I am thinking of applying the extensive reading approach to my teaching situation to approach the issue. Referring to foreign language teaching in general, Nuttall says "an extensive reading program is the single most effective way of improving both vocabulary and reading skill in general' (1982:65). This is Smith's (1985:88) "learn to read by reading". The belief that exposure to large quantities of written texts combined with effort made in reading helps to develop reading ability.

\section{Previous Research, Theory and Practice on L2 Extensive Reading}

Many researchers have emphasized the importance of including extensive reading in foreign language curricula (Day \& Bamford, 1998; Grabe, 1995b; Krashen, 1982; Paran, 1996) and numerous studies have shown the effectiveness of extensive reading in contexts of English as a second or foreign language (Elley \& Mangubhai, 1981a; Hitosugi \& Day, 2004; Mason \& Krashen, 1997). Although there are variations in the ways in which an extensive reading is administered, extensive reading programs share the basic tenet that learners self-select materials within their "linguistic capabilities" from a collection of graded readers (Day and Bamford, 1998: 126) or learners are exposed to "large quantities of materials within their linguistic competence" (Grabe and Stoller, 2002:259). According to Nation (2005), during extensive reading, students should be interested in what they are reading and should be reading with their attention on the meaning of the text rather than on learning the language features of the text. Richards and Schmidt (2002) state extensive reading is intended to develop good reading habits, to build up knowledge of vocabulary and structure, and encourage a liking for reading. Alderson and Urquhart (1984: 120) suggest that students might be free to choose their own reading material and even bring it from outside the classroom, and that the teacher might abandon formal questioning on the texts. Day and Bamford (1998) characterize extensive reading as involving a large quantity of varied, self-selected, enjoyable reading at a reasonably fluent speed.

There is now plenty of evidence that extensive reading can result in a variety of substantial language proficiency and comprehension. A study by Hayashi (1999) of the effects of extensive reading on Japanese university students' English proficiency found that students who reported reading more English books experienced significantly greater improvement in reading ability and vocabulary knowledge than those who reported reading less, as measured by pre-test and post-test. The same perception towards extensive reading was held by the students investigated by McQuillan (1994). They reported extensive reading to be not only more pleasurable, but also beneficial for language acquisition than instruction in grammar. Stanovich (2000) and his colleagues have demonstrated in multiple studies that the amount of people's overall exposure to print has a direct relation to their vocabulary knowledge and comprehension abilities. In examining the research on in-school reading and out-of-school self-reported free voluntary reading conducted in many different countries, Krashen (1993) concludes free voluntary reading or sustained independent reading results in better reading comprehension, writing style, vocabulary, spelling, and grammatical development.

However, the most convincing evidence for the benefits of extensive reading comes from the "book flood" studies (Elly \& Mangubhai, 1981b, 1983), which examined the effect of extensive reading on the English language proficiency by giving Fijian school children a large number of high-interest story books in English. These studies provide evidence of the remarkable increase on measures of language use, language knowledge as well as academic performance. In a repeated study conducted in Singapore, Elley (1991) found the students made significantly more gains in vocabulary and other language skills than the control groups. Day, Omura, and Hiramuatsu (1991) studied 191 high-school and 397 university Japanese EFL students engaged in sustained silent reading for pleasure. At the end of the treatment, they found that students in the experimental group scored significantly higher than those in the control group in correctly identifying the meaning of target vocabulary items. In an experiment comparing the improvement of reading comprehension by Japanese college freshmen taught by either a skills-based or extensive reading procedure, Bobb and Susser (1989) suggest that extensive reading may be at least as effective as skills-building, with the important advantage that it is more interesting for learners.

Quite a few studies suggest that extensive reading leads to greater writing proficiency. Janopoulos (1986) found that writing proficiency correlates positively with the quantity of time spent on reading for pleasure in the second language. 
Hafiz \&Tudor $(1989,1990)$, in studying the effects of extensive reading among students in the UK and Pakistan respectively reported statistically significant levels of improvement for the experimental groups, particularly in writing. Tsang(1996), in comparing the effects of three different programs on writing performance, also found the one that included extensive reading was significantly effective overall.

Positive effects of extensive reading on facilitating growth of learners' attitudes toward reading and increasing their motivation to read have also been reported (Cho and Krashen, 1994; Mason \& Krashen, 1997; Hayashi, 1999; Hedge, 1985; Constantino, 1994; Day \& Bamford, 1998). With specific reference to reading fluency development, extensive reading has shown to be effective in increasing reading speed and comprehension (Bell, 2001; Elly and Mangubhai, 1983; Robb and Susser, 1989).

Nuttall (1996: 127) posits a "vicious circle" to describe readers who cannot develop good reading skills. Slow readers do not read much, and if they do not read much, they do not understand. If they do not understand, then they cannot enjoy reading. Day and Bamford (1998) note that it is only through the actual reading experience that L2 or FL readers can acquire the complex linguistic, world, and topical knowledge needed to improve their reading skills. Thus, for theoretical and pedagogical reasons and based on implications from research on instructional issues, extensive reading is one of the effective methods to make up for some of the limitations of the reading done in class and to develop EFL students' reading abilities in university settings.

\section{Practical Applications of Extensive Reading to a Chinese University}

\subsection{Learners' Characteristics}

The extensive reading program is intended for the first-year Chinese majors in my university, who have just admitted to the university by passing the National University Entrance Examination. They are all native speakers of Chinese and have studied English for at least 6 years through formal instruction at junior and senior secondary schools. They have completed Band 9 of the Senior Secondary School English Standards and acquired a total of 1,800-2,000 English words. They are at the similar proficiency levels and well placed into the class on the basis of placement test scores upon entering the university. They come into the course having had practice with passages of only a few hundred words of length, because this is what is taught in the high schools and they have been taught to decode for the entrance examination. Besides, as the psychometric test atmosphere is still dominating the education in junior and senior secondary schools in China, students are burdened with all kinds of homework and exercises specially designed for exams in order to pass the entrance exams to gain entry to a key senior secondary school and a prestigious university. Reading has been used as a means to an end and is tied to exams for them. In addition, the opportunities to read in and outside class are severely limited.

\subsection{The Goal and Features of the Extensive Reading Program}

Extensive reading is a form of learning from meaning-focused input (Nation, 2005). In this program, extensive reading is viewed as an approach to teach reading in which the purpose is Sustained Silent Reading, pleasure reading (Mikuleck, 1990) or free voluntary reading (Krashen, 1993). Therefore, the principal goal is to motivate students to read and enjoy reading in order to develop their reading ability. Because of this, reading is a pleasurable activity for students, promoted as much as possible by the teacher. The features of the extensive reading program correspond with most of Day and Bamford's (2002) "Top Ten Principles for Teaching Extensive Reading", which include the fact that reading material should be within the learners' reading competence, that students are allowed to choose what they want to read, that they read as much as possible, that teachers orient and guide their students, that reading is individual and silent, that the purpose of reading is for pleasure, information and general understanding, that reading is its own reward, and hence, don't include the answering of comprehension questions as part of the activity as well as that the teacher is a role model of a reader.

\subsection{Using Graded Readers as the Reading Resource to Meet the Conditions Needed for Learning from Extensive Reading}

Extensive reading can only occur if $95 \%-98 \%$ of the running words in the text are already familiar to the learner or no burden to the learner (Hu and Nation, 2000). Nuttall (1982) recommends 1\% unfamiliar words for texts used in extensive reading. Laufer (1989) describes a study which found that below the level of $95 \%$ understanding of words in a text, comprehension was unsatisfactory. At any rate, the minimum $95 \%$ comprehension figure is the guide which is adopted in the extensive reading program. Clearly, in order to achieve this level of comprehension, students whose language proficiency is below a certain level will need to read simplified texts. Graded readers are an obvious choice with controlled vocabulary and can match students' proficiency levels. Hirsh and Nation (1992) found learners would need a vocabulary of well over 2,000 words to read the easiest fiction novels written for teenagers. This shows it is only by reading graded readers that learners like the freshman non-English majors who do extensive reading at intermediate stages of proficiency can have the density of known words that is essential for extensive reading. Above all, according to Nation (2005), learning from extensive reading should meet the following conditions: focusing on the meaning of the 
text, understanding the type of learning that can occur through such reading, having interesting and engaging books, getting learners to do large quantities of reading at an appropriate level, and making sure that learning from reading is supported by other kinds of learning. In order to meet the conditions needed for learning from extensive reading at the students' proficiency levels, it is essential to make use of simplified texts (Nation, 2005). Obviously, interesting and well-written graded readers are such simplified texts and are likely to represent the most favorable conditions for reading.

In my university, there is a large stock of graded readers with many interesting titles from Cambridge, Heinemann, Longman, and Oxford funded generously by university funds, and the World Bank loan as well as publishers' sponsorship. Therefore, a class library in each class can be set up, which is comprised of at least 40 graded readers. After one semester, the classes with the different reading resources can exchange their books to give students access to a variety of books. Because the books are kept in the actual classroom, there is a greater chance that they will be borrowed. Such a large collection of interesting books ensure that students can select what they want to read from a reasonably wide selection based on their own interest and proficiency level.

\subsection{Monitoring and Encouraging Students' Reading}

Extensive reading should ensure that students have opportunities to read at their level, on topic they select, without tests, homework or other measures of learning (Field, 2002). The students' experience of reading the text is at the center of the extensive reading experience, just as it is in reading in every life. For this reason, extensive reading is not usually followed by comprehension questions (Day \& Bamford, 2002). But how can teachers motivate students to read more and monitor their reading? Here are some of the techniques and procedures that can be effectively used.

Firstly, the teacher can ask students to fill out a short record form indicating the name of the book they have just read, its level, how long it took to read, and a brief comment on the quality of the book. This allows the student and the teacher to see at a glance how much has been read over a period of time. Secondly, students are required to present an oral report on each book they read to the class or to a reading group. These reports cover questions like what the name of the book is, what type of story it is, where and when it is set, whether it is enjoyable or well written and who would like to read. Thirdly, discussion groups consisting of four or five students can be organized to bring students together who have read the same book. As a result of the discussion, students can prepare an oral book report or a written review to present to others in the class. These activities can also help students improve their speaking and writing skills. Smith (1988: 277) notes that there is evidence that "writing is one way of promoting engagement with a text, which leads to better comprehension." Fourthly, individual counseling can provide the teacher with an opportunity to ask students about their reading experience, their progress and problems, and accordingly to approach solutions. This can be done while the rest of the class are engaged in silent reading. Finally, rewards can be given to the students for the quantity of reading they do. This will keep students excited about reading and eager to read more.

\subsection{Integrating Sustained Silent Reading in Class and Pleasure Reading out of Class}

This extensive reading program is designed to combine sustained silent reading occurring within class time and pleasure reading outside class time. In class, one of the six 45-minute class periods allocated to college English is devoted to sustained silent reading as well as to activities like retelling the stories orally to the reading group or to the class, information transfer and 'read and write'. During sustained silent reading, there is no reading instruction, no teacher intervention or evaluation, only reading for pleasure. Besides, the teacher serves as a role model. Ideally, 20 minutes is set aside for sustained silent reading and the remaining 25 minutes are used for classroom activities. The benefits resulting from sustained silent reading are many, including student autonomy, improved identification and interpretation skills (Silberstein, 1994), vocabulary gain (Day, Omura and Hiramatsu, 1991; Krashen, 1993) as well as improved spelling and an enjoyment of reading (Krashen). Retelling the stories would give students an opportunity to share their stories with their classmates and to practice their oral English. Information transfer activity helps students to build up a diagram or "visual" from the information read by them. The visual then becomes the basis of a second information transfer in which students reproduce the information linguistically in either a spoken or written mode. As only 45-minute in-class reading is insufficient for the development of an adequate L2 reading ability. One measure which can make up for deficiencies in classroom reading opportunities is for students to engage in out-of-class pleasure reading. Students should spend on average about 3 to 4 hours per week reading the reading program books outside classroom. Teachers can do a lot to help students pursue such extensive reading. The out-of-class pleasure reading has the effect of improving students' reading skills, their confidence, and self-identification as readers (Kitao, Yamamto, Kitao and Shimatani, 1990; Stoller, 1994)

\subsection{The Minimum Requirements of the Extensive Reading Program}

We plan to monitor the progress of the extensive reading program over one academic year. In the first semester students should read at least one graded reader every two weeks and read at least 8-12 in one semester. In the second semester, students are encouraged to read one per week. After one year of extensive reading, students should read at least 30 
books and their reading ability are expected to meet the basic requirements for reading in College English Curriculum Requirements. With the extensive reading program progressing for another academic year, their reading ability will develop to a point where they are able to read large quantities of difficult texts.

\section{Conclusion}

The teaching of reading dominates the EFL situation in China, and the extensive reading program reported here suggests the extensive reading is an effective and pleasurable way for undergraduates to learn to read English as a foreign language as an alternative to intensive reading courses. By combining sustained silent reading and out-of-class pleasure reading, students gradually move from a learning-to-read orientation to a reading-to-learn framework. By reading what they choose and enjoying their reading students have a great deal of flexibility, which caters to the different needs and interests of individual students and allow them to develop their reading competence at their own rates. As a result, students' motivation to read will increase, which will in turn benefit their eventual acquisition of the target language. In addition, under the extensive reading program, the interests of students are best served as control of the reading activity is left in their hands rather than those of the teacher with respect to choice of topic, text type and difficulty. Students are permitted to assume responsibility for their own learning, which also helps them to a position of independence of the teacher and is ultimately essential for the development of learner autonomy. However, the proposal has its constraints. First, it needs research to test the effects of extensive reading on students' reading ability. Second, teachers' shared understanding of the benefits of the extensive reading should be emphasized. Considering there are clear mismatches between teachers' and learners' opinions about the extensive reading, research is needed to learn about the language goals of the university-level students and to suggest how they can be met without abandoning teachers' or program's goals. Third, some new techniques should be explored to be used in the extensive reading program, such as using online discussion board.

\section{References}

Alderson, J. C. and Urquhart, A. H. (1984). Reading in a Foreign Language. London: Longman.

Bell, T. (2001). Extensive reading: Speed and comprehension. The Reading Matrix, 1, 1. http:// www.readingmatrix.com/articles/bell/index.html

Cho, K. and Krashen, S. (1994). Acquisition of vocabulary from the Sweet Valley Kids series: Adult ESL acquisition. Journal of Reading, 37, 8, 662-667.

Constantino, R. (1994). Pleasure reading helps, even if readers don't believe it. Journal of Reading, 37, 6, 504-505.

Day, R. R. and Bamford, J. (1998). Extensive reading in the second language classroom. Cambridge: Cambridge University Press.

Day, R. R. and Bamford, J. (2002). Top ten principles for teaching extensive reading. Reading in a Foreign Language, $14,2,136-141$.

Day, R. R., Omura, C. and Hiramatsu, M. (1991). Incidental EFL vocabulary learning and reading. Reading in a Foreign Language, 7, 2, 541-551.

Elley, W. B. (1991). Acquiring literacy in a second language: The effect of book-based programs. Language Learning, $41,3,375-411$.

Elley, W. B. and Mangubhai, F. (1981a). The impact of a book flood in Fiji primary schools. Wellington: New Zealand Council for Educational Research and Institute of Education.

Elley, W. B. and Mangubhai, F. (1981b). The long-term effects of a book flood on children's language growth. Directions, 7, 15-24.

Elley, W. B. and Mangubhai, F. (1983). The impact of reading on second language learning. Reading Research Quarterly, 19, 1, 53-67.

Field, M. L. (2002). Really reading? Guidelines, 24, 1, 4-9.

Grabe, W. (1995a). Dilemmas for the development of second language reading abilities. Prospect, 10, 2: 38-51.

Grabe, W. (1995b). Why is it so difficult to make extensive reading the key component of L2 reading instruction? Paper presented at the Reading Research Colloquium, Annual TESOL Convention, Long Beach, CA.

Grabe, W. and Stoller, F (2002). Teaching and researching reading. Harlow, UK: Longman.

Hafiz, F. and Tudor, I. (1989). Extensive reading and the development of language skills. English Language Teaching Journal, 43, 4-11.

Hafiz, F. and Tudor, I. (1990). Graded readers as an input medium in L2 learning. System, 18, 1, 31-42.

Hayashi, K. (1999). Reading strategies and extensive reading in EFL classes. RELC Journal, 30, 2, 114-132. 
Hedge, T. (1985). Using readers in language teaching. London: Macmillan.

Hirsh, D. and Nation, I. S. P. (1992). What vocabulary size is needed to read unsimplified texts for pleasure? Reading in a Foreign Language, 8, 689-696.

Hitosugi, C. and Day, R. R. (2004). Extensive reading in Japanese. Reading in a Foreign Language, 16, 1, 91-110.

$\mathrm{Hu}, \mathrm{M}$. and Nation, I. S. P. (2000). Unknown vocabulary density and reading comprehension. Reading in a Foreign Language, 13, 1, 403-430.

Janopoulos, M. (1986). The relationship of pleasure reading and second language proficiency. TESOL Quarterly, 20, 763-768.

Kitao, K., Yamamoto, M., Kitao, S. K. and Shimatani, H. (1990). Independent reading in English-use of graded readers in the library English as a second language corner. Reading in a Foreign Language, 6, 2, 383-398.

Krashen, S. D. (1982). Principles and practice in second language acquisition. New York: Prentice Hall.

Krashen, S. D. (1993). The power of reading: Insights from the research. Englewood, CO: Libraries Unlimited.

Laufer, B. (1989).What percentage of text-lexis is essential for comprehension? In C. Lauren and M. Nordman (Eds.), Special Language: From Humans Thinking to Thinking Machines, Clevedon: Multilingual Matters.

Li, X. (1984). In defense of the communicative approach. In Y. F. Dzau (Eds.), English in China. Hong Kong: API Press.

Mason, B. and Krashen, S. (1997). Extensive reading in English as a foreign language. System, 25, 1, 99-102.

Mc Quillan, J. (1994). Reading versus grammar: What students think is pleasurable for language acquisition. Applied Language Learning, 5, 2, 95-100.

Mikulecky, B. (1990). A short course in teaching reading skills. Reading, MA: Addison-Wesley.

Nation, I. S. P. (2005). Teaching Reading and Writing. Student Notes Distribution Center. School of Linguistics and Applied Language Studies. Victoria University of Wellington.

Nuttall, C. (1982). Teaching Reading Skills in a Foreign Language. London: Heinemann Educational.

Nuttall, C. (1996). Teaching reading skills in a foreign language $\left(2^{\text {nd }}\right.$ edition). Oxford: Heinemann.

Paran, A. (1996). Reading in EFL: facts and fictions. ELT Journal, 50, 1, 25-34.

Richards, J. C. and Schmidt, R. (2002). Longman dictionary of language teaching and applied linguistics ( $3^{\text {rd }}$ edition). London: Longman.

Robb, T. N. and Susser, B. (1989). Extensive reading vs. skills building in an EFL context. Reading in a Foreign Language, 5, 2, 239-251.

Siberstein, S. (1994). Techniques and resources in teaching reading. New York: Oxford University Press.

Smith, C. B. (1988). Does it help to write about your reading? Journal of Reading, 32, 3, 276-277.

Smith, F. (1985). Reading without Nonsense ( $2^{\text {nd }}$ edition). New York: Teachers College Press.

Stanovick, K. (2000). Progress in understanding reading: Scientific foundations and new frontiers. New York: Guilford Press.

Stoller, F. L. (1994). Developing a focused reading lab for L2 students. Reading in a Foreign Language, 10, 2, 33-53.

Tsang, W. (1996). Comparing the effects of reading and writing on writing performance. Applied Linguistics, 17, 2 , 210-233.

Urquhart, S. and Weir, C. (1998). Reading in a Second Language: Process, Product and Practice. London, Longman.

Williams, R. (1986). “Top ten” principles for teaching reading. ELT Journal, 40, 1, 42-45. 